\title{
PROBLEMS OF 14-18 YEARS OLD YOUTH AND THE TRENDS OF ORGANISATION OF PREVENTION ACTIVITIES: LITHUANIAN CASE
}

\author{
Sandra Valantiejienė
}

Mykolas Romeris University, Lithuania, valantiejiene@gmail.com

\begin{abstract}
The World Health Organization (since 1998) recognises that many modern diseases and disorders (including social problems) are caused by risky behaviour. Youth risky behaviour is generally defined as a behaviour that directly or indirectly threatens the young person's well-being and health. This is usually understood as smoking, abuse of alcohol and psychoactive substances and early initiated and unprotected sexual relations. However, the risky behaviour also includes basic things such as the failure to comply with diet regimen, sedentary lifestyle, not wearing the safety belt in the car and failure to wear a helmet whilst cycling or rollerblading. Adolescence itself is a risky span of the human life, as it is associated with moving from childhood into the adult world and intensive search for the personal identity. To ensure a consistent development of personality, adolescent risky behaviour prevention include harmonisation of education processes to help teenagers to develop responsible behaviour skills by reducing the risk factors and increasing protective factors. The article aims to overview the factors that influence youth risky behaviour and the factors that determine the planning and organisation of preventive activities for the pupils in the higher classes of the schools of general education. The study was completed in the form of a questionnaire that was conducted in the schools of the Lithuanian Republic in 2016. The results of the study describe trends of the prevention policies applied in the system of education, considering the national context of the individual Member States of the European Union.
\end{abstract}

Keywords: youth risky behaviour; adolescence; prevention of risky behaviour; schools of general education.

JEL Classification: I21; I28; I29.

\section{Introduction}

Recently, in the world and in Lithuania, much attention is paid to the research on adolescent behaviour and the implementation of prevention activities in general education schools. The term 'prevention' (Lat. praevenire - preventing) is generally understood as an activity for controlling certain negative phenomena in human and society life or to reduce their potential effects (Dictionary of International Words 2000).

In the sphere of social relations, prevention is defined as a certain social policy and social activity that is used to reduce specific and predictable problems of society, protect public welfare and develop desirable forms of person's behaviour (Valantiejiene et al. 2010). The theoretical and practical analysis of preventive activities is particularly important for the science of education because the value system of children as participants in the educational system is very fragile and quickly affected (Bankauskiene 2013). Thus, the negative factors and the risky behaviour influenced by the negative factors especially harm young people and children because the system of their values is still not formed. In addition, the formation of the education system is significantly impacted by economic changes, the growing popularity of new media and other factors that are known to have negative social effects. To control these negative effects, children need to be taught skills of decision-making, motivation, flexibility and self-control to effectively manage their life (Lopes, Solovey 2004; Sklad et al. 2012; Farmer et al. 2013). Therefore, protection against negative social phenomena such as violence, bullying, alcohol, drugs, tobacco, suicide and non-attendance of school greatly contributes to the development of students' learning environment that supports safe and healthy lifestyle (Reeves, Kanan, Plog 2010) and reduction of risky behaviour amongst adolescents. The specified circumstances determine the relevance of chosen theme and its practical significance in the context of the science of education (educology/pedagogics). 
It is also important that the provisions of the legislation enacted by the United Nations, the European Union and the Republic of Lithuania (e.g. Law on Education of the Republic of Lithuania, 2016) emphasise that a safe school environment is the most important factor for the implementation of general prevention oriented to all children. The implementation of systematic prevention activities in schools of general education reduces aggressive behaviour and probability of psychoactive substance abuse; improves children's mental health, their academic achievements and the microclimate in the classroom; and develops the behaviour that is accepted in society. For this purpose, certain preventive programmes are also implemented in Lithuanian general education schools. The preventive programme as the systematically implemented activity that is structured and formalised according to pre-defined model can be named as one of the most effective forms of preventive activities to help achieve the desired results. Over the past 10 years, much attention has been paid to prevention programmes in the Lithuanian general education schools. The aim of this study is to determine the prevalence of risky behaviour characteristics of 14- to 18-year olds and to compare them with the preventive measures used in general education schools. To achieve this aim, the following objectives were formulated in this article: (1) to analyse the general theoretical components of adolescent risky behaviour, (2) to investigate the characteristics of prevalence of risky behaviour amongst 14- to 18year-old Lithuanian pupils and (3) to determine the selected preventive activities for the reduction of adolescent risk behaviour in general education schools of Lithuania. The problematic research question was chosen: how risky teen behaviour responds to selected preventive activities in general education schools?

Quantitative research methods were selected to analyse the problematic question of the study. Quantitative analysis was used to carry out the risky behaviour assessment questionnaire survey of young people (Youth Risk Behavior Survey 2017). The obtained data was compared with the survey of Lithuanian general education schools on the implementation of prevention programmes in general education schools in the 2015-2016 academic year (see Auškelis et al. 2016), and the results of the comparison are the basis for the conclusions of the article.

\section{Literature Review}

Risky behaviour of adolescents. The World Health Organization recognises that many diseases and disorders are caused by risky behaviour. The risky behaviour in literature is defined as behaviour that directly or indirectly harms the young person's well-being, health and even the progress of life (Jessore 1998, Irish 2011; Whitesell et al. 2013), the investigators of the United States (e.g. Eaton et al. 2012) describe the deleterious behaviour as risky behaviour, which is attributed to the forms of behaviour that are the main causes of morbidity and mortality. In addition, six types of health-risk behaviours are listed: (1) unsafe behaviour (not wearing a helmet whilst cycling, not wearing the safety belt in the car, travelling with intoxicated drivers, carrying of weapons and so on.), (2) smoking, (3) using alcohol and other psychoactive substances, (4) sexual behaviour, (5) an unhealthy diet and (6) physical inactivity. Risky behaviour often starts at a very early age and forms in adolescence (Costa 2008). Adolescence itself is a risky stage of the human life. During the stage of adolescence, teenagers intensely search their personal identity and move from childhood into the adult world, so they often plunge into the extremes, they often face a variety of objections, the desire to take risks (Dowell, Burgess, Cavanaugh 2009). Besides, during adolescence, such risk factors occur that could easily lead to further long-lasting changes in the behaviour of adolescents (Pickett et al. 2002).

In recent years, there were more and more discussions about the risky behaviour of young people in Lithuania. According to the results of a study of Pupils health and lifestyle (Healthy Behaviour of School Children), the prevalence of risk behaviour amongst young people is so large that the existence of an epidemic of risk behaviour can be stated (Starkuviene, Zaborskis 2005). The behaviour that is harmful to the health is the cause of diseases and deaths; therefore, it is important to implement the prevention of such behaviour in childhood and especially in adolescence (Keeler, Kaiser 2010). Sociodemographic factors make a huge influence on adolescent risky behaviour as well, and the researchers confirm that the risky behaviour is very related to two factors - age and gender (Costello et al. 2008; Olsson et al. 2008; Ruangkanchanasetr et al. 2005). Scientific studies also confirm that the riskiest types of behaviour are more common for boys than for girls (Eaton et al. 2012; Sychareun, Thomsen, 
Faxelid 2011; Starkuviene, Zaborskis 2005). It also states that the risky behaviour is characteristic which is especially prevalent in the stage of adolescence (Pickett et al. 2002; Feldstein, Miller 2006). Other scientists emphasise the connection of risky behaviour not only with morbidity and mortality but also with all the personal development and well-being (Guzman, Bosch 2007). Risky behaviours can influence that a young person will not be able to finish school or will have enough free time with to spend with his or her peers. The reason for this might be the consequences of various risky behaviours - teenage pregnancy determined by unprotected sex, living in the rehabilitation community because of the drug use, long medical treatment after the injury and so on (Duberstein et al. 2000).

In addition, adolescence as a biological phenomenon begins with the sexual maturation. This is one of the most important periods in the development of health. The behavioural and lifestyle characteristics and approach to health in this period often determines the quality of life in the future (Kardelis et al. 2001). Many scientists in Lithuania and other foreign countries have analysed adolescent problems and approaches of teenagers to their body during adolescence (Erikson 2004; Lenhart 2009). They identified the developmental stages of adolescence, its influence on the formation of personality, understanding and formation of the image of adolescences' own body. For example, Sakalauskaite and Tutkuviene (2009) argued that the image of the perfect body usually is more important for women than for men, that's why to most girls, especially during adolescence, their appearance is very important. However, striving to reach the ideal of the perfect body, teenagers often break the principles of a healthy diet, which results in states such as bulimia, anorexia nervosa and obesity. Research has shown that in other countries and in Lithuania, eating disorders are common amongst women and girls (ratio between boys and girls is 1:20 (Gaigalaite 2007)). It should be emphasised that healthy behaviour habits that formed in adolescence can affect the rest of former adolescences life (Norkus 2012).

Keeler and Kaiser (2010) distinguish three main components of risky behaviour: risk and protective factors, risky behaviour itself and its consequences to the health. The authors investigated the risk and protective factors and the importance of risky behaviour. According to them, protective factors increase the possibility to engage in risky behaviour. Protective factors also have a significant impact on risky teen behaviour. Adolescents who have more friends in their own environment (in school and outside of school) are more satisfied with their lives in the environment where they feel more confident and are getting involved in less risky behaviours (Bulotaite 2009; Livingstone, Helsper 2008; Wasserman et al., 2003). Teenagers whose relationship with their parents and peers are not strong will likely consume more alcohol, smoke or will use unsafe search possibilities in online communication (Christofidis et al. 2012). Whilst analysing the risky adolescent behaviour problems, more and more authors are focusing on adolescent behaviour in social networks (Christofidis et al. 2012; Kolpakov et al., 2012; Guan, Subrahmanyam 2009; Lenhart 2009). An important factor that limits the risky behaviours of young people is a feeling of safety at school. The sense of security is one of the main requirements to ensure a consistent development of personality (Milam, 2010; American Psychological Association Zero Tolerance Task Force 2008, Astor et al. 2009).

The main goal of preventive activities in the school of general education is strengthening protective factors for teenagers. It is also an important measure to prevent risky behaviour. Various ways are being researched to reduce the risk factors to stop this behaviour. Many types of prevention of risky behaviour in Lithuanian general education schools are included in the implementation of preventive activities at schools, such as smoking, alcohol and drug abuse prevention actions; preventive activities on stopping suicidal behaviour or violence; and so on. It is expected that these preventive programmes and activities will provide information to the person about the consequences of the negative, harmful behaviour and will help to develop social skills that will affect a teenager's decision to abandon risky behaviour and choose a safer behaviour (Green et al. 2000; Branstrom et al.; June 2007; Lopes, Solovey 2004; Sklad et al., 2012; Farmer et al. 2013).

Preventive activities in Lithuanian general education schools. The start of preventive activities in Lithuanian schools can be traced back to 1999 when the Government of the Republic of Lithuania approved the National Drug Control and Drug Prevention Programme for 1999-2003, which was the basis of the state-wide initiation of organisation of systematic preventive measures in general 
education schools, such as analysing existing instruments and resources, setting up various commissions on the organisation of preventive actions, publishing of methodical literature, ensuring of teachers' professional development in this field, professional involvement into the international studies on drug use in European schools (the European School Survey Project on Alcohol and Other Drugs; ESPAD), initiatives to fund prevention activities in general educational schools and implementing the competitions to gain additional funding for preventive activities (Valantiejiene et. al. 2010, Bankauskiene 2014). In later periods, a lot of different types of legislation sources were enacted, which formed the basis for preventive actions in the education system and which were aimed to prevent the use of alcohol, tobacco and other psychoactive substances; to pre-empt suicides; to preempt the prevalence of HIV/AIDS as well as to preclude violence and legal offenses. These activities were related to the strategic priorities at the state level in the field of preventive actions: to make prevention work more as school's daily routine in formal and non-formal education; analyse the causes of students' risky behaviour, promote the development of targeted prevention programs and apply them as needed; to ensure the quality of targeted prevention programmes. During this period, the preventive action planning and their implementation practices have changed several times. The development of a safe environment for school, the self-education of mature personality and academic achievement issues were also analysed at the national level (The National Centre for Special Needs Education and Psychology 2016). In 2016, the decisions were made on the legislative level concerning the implementation of mandatory preventive programmes in schools for the 2017-2018 school year. Besides, para. 11 of Article 43 of the Law of Education of the Republic of Lithuania (2011) has established that every educational institution must allow each student (pupil) to take part in at least one coherent, long-term, preventive programme where social and emotional competencies are developed on the regular basis, including programmes on the prevention of violence, use of alcohol, tobacco and other psychoactive substances and promotion of health and other types of programmes approved by the recommendations of the Minister of Education. These provisions also require the leaders of all schools to carry out prevention programmes. Accordingly, at this stage, the issue of quality of prevention programmes becomes very important as well as responsible decisions of school heads when choosing them, whilst Committee of the child welfare has an important role as an advisory body in each school of general education. In conclusion, it can be stated that various authors define risky behaviour of young people as a behaviour that directly or indirectly endangers the well-being of a young person. Mostly, this behaviour occurs in adolescence when the search of personal identity starts. The researches carried out by other authors also confirm that the riskiest types of behaviour are more common for boys than for girls. Therefore, when working with adolescents, it is necessary to strengthen the protective factors and reduce the risk factors. Whilst strengthening the protective factors, the most effective preventive measure is the implementation of prevention programmes, and therefore, their practical implementation in Lithuania (based on the conducted quantitative research/empirical study) is presented in other sections of this article.

\section{Methodology}

The stages of the empirical study. To assess the identified problems on a practical level, a quantitative study was conducted in two stages. The use of assessment questionnaire about risky behaviour of young people was selected in the first phase of the quantitative investigation (Youth Risky Behavior Survey 2017). This questionnaire was designed to determine the prevalence of risky behaviour between pupils. The 11 groups of questions were identified and used in the questionnaire according to the recommendations provided by authors such as Eaton et al. (2011). Therefore, the questionnaire consisted of questions about the personal safety; about carrying of the weapons, about bullying, about attempts to commit suicide and tobacco use; about the electronic cigarette smoking, alcohol consumption and smoking of marijuana; about using of other psychoactive substances; about sexual relations; and about body weight, eating breakfast and physical activity. According to the results of other conducted studies in Lithuania (such as European School Survey Project on Alcohol and Other Drugs (ESPAD)), a block of questions about the use of other psychoactive substances (except marijuana) has been removed from the questionnaire because the data of the ESPAD study has shown the low consumption of such psychoactive substances in Lithuania. Additionally, the group of 
questions related to carrying guns (weapons) to school was removed. We should note that the surveys about youth risky behaviour in the United States usually always ask about carrying weapons because such behaviour is quite common amongst students (pupils). However, such questions were considered as not suitable in Lithuanian context. To reveal smoking (including electronic cigarette smoking), alcohol and marijuana smoking habits, the questions in the questionnaire have been harmonised with the European model questionnaire of the European Drugs and Drug Addiction Monitoring Center (EMCDDA 2009), which is also used in the studies of psychoactive substance abuse that are carried out by the Drugs, Tobacco and Alcohol Control Department of the Republic of Lithuania.

The general characteristics of the respondents. The questionnaires were filled in by 196 students. The random sampling of pupils has been selected as a basis for the questionnaire survey. The principle for selecting the sample was nested random sample, which means that the classes in schools from the city of Vilnius were randomly selected and the sample was formed from all the pupils in the class whose parents signed the written consent to participate in the study. Random survey sample was selected to ensure that the results of questionnaire survey would be sufficiently comprehensive and reliable and to avoid any intentional bias (e.g. based on gender) in the process of formation of the research sample.

About 69 (34.4\%) of participants were girls and 127 boys (65.6\%). The study included ninth to eleventh grade students, of which $21.5 \%$ were students of the ninth grade, $52.7 \%$ tenth grade and $25.8 \%$ eleventh grade. The age of the respondents was as follows: $2.2 \%$ were 14 -year olds, $19.9 \% 15$ year olds, $54.3 \% 16$-year olds, $23.1 \% 17$-year olds and $0.5 \% 18$-year olds. It should be noted that even $75.3 \%$ of respondents live with both parents, $22.6 \%$ with a single parent, $1.6 \%$ in foster homes and $0.5 \%$ with foster parents, grandparents or other relatives.

The sample and the participants of the survey. The study was conducted in December of 2016, and the sample of the survey was calculated according to the data of Lithuanian Education Management Information System (ITC Education Management Information System 2017). According to the data of this System, in the academic year of 2016-2017, in total, 78,504 ninth to eleventh grade students has studied in schools of general education in Lithuania. The gymnasiums of Vilnius, in which students are accepted without entrance examinations, were selected for the second stage. The survey sample has been determined with $95 \%$ accuracy with $7 \%$ error of calculation: $\mathrm{n}=196$. By simple random sampling, one ninth, tenth and eleventh grade was selected from each school. From the city of Vilnius (capital of the Republic of Lithuania), 14-18 years old pupils were selected for the forming of the survey's sample because according to the data of Lithuanian Education Management Information System (ITC Education Management Information System 2017), one-third of all Lithuanian pupils are studying in the Vilnius city. So, it was assumed that the investigation (surveying) of pupil's population in Vilnius can better disclose trends of the total Lithuanian pupil's population.

Processing of the empirical research data. Collected data was analysed by using the SPSS 22.0 software. The specific questions of the survey's questionnaire were analysed jointly and severally according to gender, age and grade of learning classes. Mann-Whitney, Kruskal-Wallis and $\chi^{2}$ methods were used for the analysis of categorical data (nominal and ordinal variables). Prevalence estimates were calculated by applying $95 \%$ confidence intervals. Continuous amounts were analysed based on Student's t-test and ANOVA (the analysis of variance) statistical test. The criteria of Kolmogorov and Smirnov, Shapiro and Wolf, Pearson's as well as chi-square were used for the processing of the statistical data. The coefficient of Spearman correlation, Mann-Whitney criteria and multiple linear regression was also applied in this process.

In the second stage of the research, the data obtained during the questionnaire survey was compared with the overall results describing the preventive actions in the Republic of Lithuania, which was received during the state-organised Survey of the Lithuanian general education schools on the implementation of prevention programmes in general education schools in the 2015-2016 academic year. This survey was aimed to assess the implementation of prevention programmes, the scale and characteristics of the use of methodological instruments in the Lithuanian general education schools and to project the potential directions for the improvement and development of preventive activities. It should be noted that $98 \%$ of all Lithuanian general education schools were surveyed during this study. 


\section{Results}

In total, 196 questionnaires answered by pupils (whose parents or guardians signed an agreement to participate in the survey) were analysed during the questionnaire survey. From all the pupils surveyed, $69(34.4 \%)$ were girls and 127 boys $(65.6 \%)$. The pupils of ninth to eleventh grades have participated in the survey, from them $21.5 \%$ were of the ninth grade, $52.7 \%$ tenth grade and $25.8 \%$ eleventh grade. According to their age, respondents were distributed as following: $2.2 \%$ of the respondents were 14 years old, $19.9 \% 15$ years old, $54.3 \% 16$ years old, $23.1 \% 17$ years old and $0.5 \% 18$ years old. It should be noted that even $75.3 \%$ of all respondents lived with both of their parents, $22.6 \%$ with one of their parents, $1.6 \%$ lived in a foster homes or boarding schools and $0.5 \%$ lived with the foster parents, grandparents or other relatives.

The conducted study (questionnaire survey) raised the hypothesis that well-being feeling of boys and girls in school are different and this may affect the risky behaviours. It was expected that the feeling of girls was better than boys. The results showed that the average rank of males (mean rank 91.00) is less than that of girls (average rank of 95.38), but no significant difference between the well-being of the schoolboys and schoolgirls were found $(\mathrm{p}=0.594)$, so we cannot argue that boys and girls feel differently at school. Calculated signal strength was -0.0390 , that is, it means very small gender effect to the feeling of safety in school. Thus, the feeling of security and well-being in school doesn't depend on the character of gender.

Evaluation of the risky behaviour. Results of the survey based on the analysis of the group of questions about personal security protection in certain life situations showed that risky behaviour rates of boys are significantly higher than those of girls, especially behaviour related to driving using various means such as bikes, skateboards and roller skaters and not wearing a helmet and other safety measures $(p=0.006)$. The results of the survey showed that $82.2 \%$ of boys and $33.1 \%$ girls never wear a helmet whilst cycling, skateboarding or rollerblading. Risky behaviour rates of boys are significantly higher than those of girls $(\mathrm{p}=0.004)$; when they were answering about travelling with a vehicle that is driven by a drunk person, $59.8 \%$ boys and $34.8 \%$ girls agreed that they would travel together with someone who is driving a vehicle after drinking alcoholic beverages. The boys are much more involved in fights on school grounds $(p=0.008)$ - even $91.7 \%$ of boys and only $8.3 \%$ of girls said that they were sometimes involved in a fight on school grounds. The results showed that risky behaviour rates of girls are significantly higher than those boys when they were answering about staying in the same room with a smoking person $(\mathrm{p}=0.001)$. For example, only $14.8 \%$ of boys and $37.9 \%$ girls have indicated that they always stay in the same room with a person who is smoking (Fig. 1).

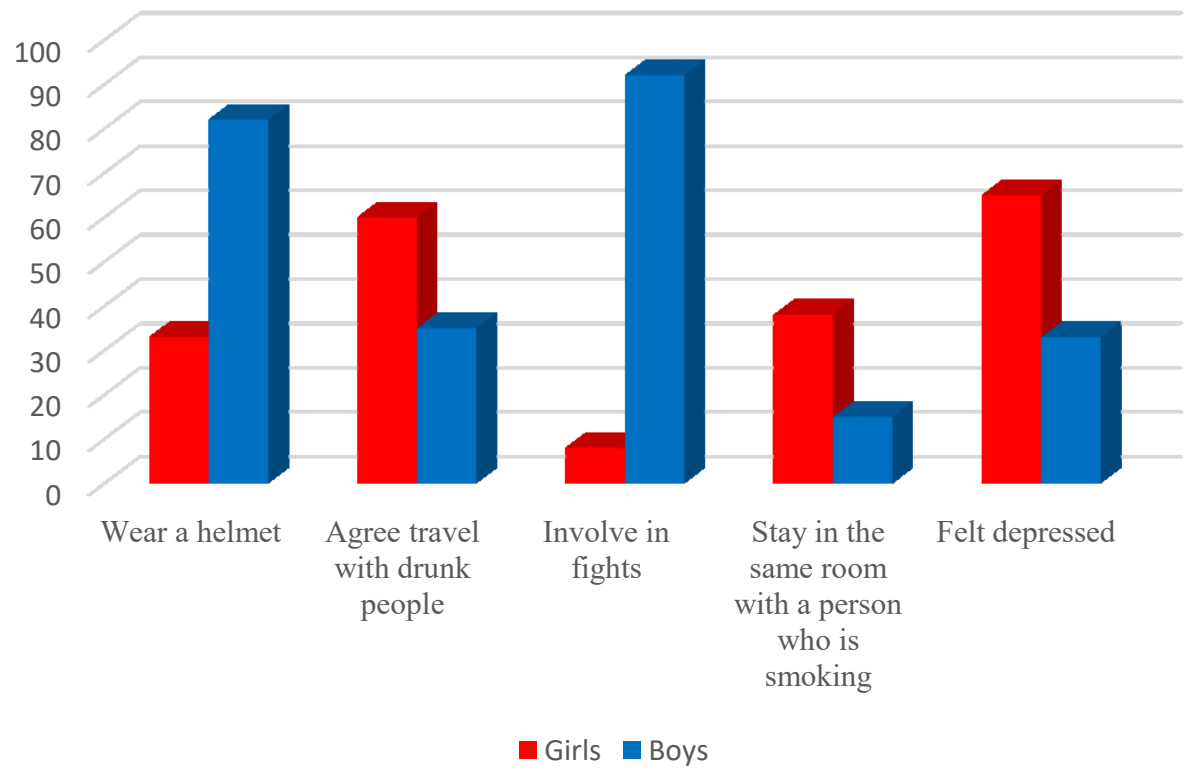

Fig. 1. The forms of risky behaviour between respondents (expressed as a percentage) 
The study was also designed to evaluate how many pupils are at risk of harm to their health when (i) they are staying in a room with someone who is smoking, (ii) they are consuming alcohol daily and (iii) they are occasionally taking other drugs. On the basis of the application of the Friedman criterion to the results of the survey, it was noticed that the approach to the risky behaviour differs between the pupils surveyed and the attitude of the students to a three different risk types was statistically significant ( $\chi 2=86.448, \mathrm{df}=2, \mathrm{p}=0.000$ ). The pupils have evaluated daily alcohol consumption as the biggest risk (the average estimate is 2.23), much lower risk was attributed to the occasional use of drugs (the average estimate is 2.09) and the lowest risk was attributed towards staying in a room with a person who is smoking (the average estimate is 1.58 ).

The study was also aimed to find out how much the attitudes of boys and girls differ towards the risks to harm their health by a daily alcohol consumption and occasional smoking of cigarettes. The results showed that approach of pupils (the difference between different sexes (boys and girls) was not established) to these two variables was statistically significant $(p=0.004)$, and amongst the same surveyed pupils, in 105 cases, the risk of daily consumption of alcohol was considered better and in 19 cases, daily alcohol consumption risk was considered worse. Thus, it can be concluded that the opinion of both boys and girls towards the daily consumption of alcohol is that daily consumption of alcohol is riskier than occasional smoking.

Besides, one of the additional aims of the study was to examine an approach to the three groups of respondents (students of ninth, tenth and eleventh grades) towards the risk to harm their health when cannabis is regularly smoked. A statistically significant difference $(p=0.004, d f=1)$ was established: the ranks average of the eleventh grade students was 113.27, tenth grade students was 94.25 and ninth grade students was 67.20. As we can see from the differences in the ranks, the greatest risk of harm to their health when cannabis is regularly smoked is attributed by pupils of eleventh grade and the lowest risk by pupils of the ninth grade.

Assessment of bullying and prevalence of depression. The Lithuanian study on Health Behaviour in School-aged Children (HBSC) which was carried out in 2014 shows that bullying in school affects almost every third pupil: $31.2 \%$ of boys and $27.7 \%$ of girls $(\mathrm{p}<0.05)$. The results of the questionnaire survey carried out by the author showed relatively similar results, that is, $37.6 \%$ of 14 - to 18 -year olds have been bullied in the school environment, whilst $31.4 \%$ of pupils have experienced bullying in cyberspace (via text messages, e-mails or social networks). From the pupils who experienced bullying, boys more often than girls were getting bullied $(\mathrm{p}=0.002)-61.4 \%$ of boys and $38.6 \%$ of girls reported that they were bullied in a school environment. Comparison of the numbers of bullying by age shows that pupils in the upper classes (despite the gender of pupils) are more exposed to bullying. Fifteen-year olds were bullied four times less than 16-year olds - respectively $15.7 \%$ and $64.3 \%$ were bullied $(\mathrm{p}=0.001)$. We should note that according to the questionnaire survey, the level of bullying is declining again between 17 years old $(18.6 \%)$ and significantly decreases between 18 years old $(0.1 \%)$. From the other established trends, we may note that girls are more often bullied in the cyberspace $(39.2 \%)$ than boys $(27.3 \%)(\mathrm{p}=0.002)$.

The analysis of the answers of pupils who participated in the survey, conducted by the author, also shows that $33.1 \%$ of boys and $64.1 \%$ of girls $(p=0.000)$ has indicated that at least once they felt so sad and without hope that they ceased to engage in their normal activities. Comparison of the prevalence of depressive state of mind according to the age factor (as no gender-related differences were found $(\mathrm{p}=0.123))$ shows that the 16 - and 17-year-old students have experienced this state twice more often (49.5\% and 50.0\%, respectively) than $14-$ and 15 -year olds $(25.0 \%$ and $24.3 \%$, respectively). The prevalence of the depressed mood in adolescence is a major public health problem, as it is related to a high risk of suicide. The results also showed that girls $(39.1 \%)$ have contemplated suicide whilst being in a sad mood twice more often than males $(19.2 \%)(\mathrm{p}=0.002)$.

Assessment of the prevalence of psychoactive substance abuse. According to the questionnaire survey, $65.1 \%$ of 14 - to 18 -year olds $(69.7 \%$ males and $56.3 \%$ females, $\mathrm{p}=0.001)$ have ever tried smoking cigarettes. The number of pupils who tried to smoke ranged from $59.4 \%$ to $81.1 \%$ according to different ages of students. The largest numbers of pupils who had tried smoking were recorded between 15-year-old students (81.1\%), and the smallest numbers between 16-year-old students 
$(59.4 \%)(\mathrm{p}<0.001)$. The data of the survey shows that the age when pupils tried to smoke for the first time ranges from $7.5 \%$ (9- to 10 -year olds) to $24.7 \%$ (13- to 14 -year olds). The survey also detected that in the last 30 days, $75.8 \%$ of boys and $56.7 \%$ girls did not smoke at all. From the pupils who have smoked in the last 30 days, $7.5 \%$ of boys have indicated that they smoked every 30 days and $13.3 \%$ of girls have indicated that they smoked at least 1-2 days from an overall 30 days period. The prevalence of smoking amongst pupils that was detected by the author is similar to the results of European School Survey Project on Alcohol and Other Drugs (ESPAD) survey conducted in 2015.

The study found that $81.2 \%$ of the respondents $(77.9 \%$ of boys and $87.5 \%$ of girls, $p=0.001)$ tried to consume the alcoholic beverages at least one time in their life. The consumption of alcohol that occurred several times in a week was reported by $16.9 \%$ of respondents, more often by boys than girls ( $20.6 \%$ of boys and $11.5 \%$ of girls has indicated this factor) $(\mathrm{p}<0.001)$. About $35.5 \%$ of boys have stated that they drank alcohol for the first time at 13-14 years of age, and $28.1 \%$ of girls stated that they drank alcoholic drinks for the first time at 15-16 years of age.

According to the results of the survey, at least $35.5 \%$ of respondents notified that they have ever tried smoking cannabis at least once $(37.7 \%$ males and $31.3 \%$ females, $\mathrm{p}<0.001)$. Both boys and girls tried smoking cannabis mainly at $15-16$ years of age (23.0\% of boys and $20.3 \%$ of girls).

Assessment of sexual behaviour. The risky sexual behaviour of adolescents is an important component for the evaluation of (un)healthy behaviour, and the key factors of it are the age when sexual relations starts and occurrence of sexual relations without using protection means. The analysis of data showed that $26.5 \%$ of respondents have had sexual relations at least once and from them, only $45.8 \%$ used adequate protective means (by $47.1 \%$ of boys and $42.9 \%$ of girls). Both boys and girls (a statistically significant difference between different gender types was not determined) usually start sexual relations at the age of 15-16. According to the data of the survey, we should note that sexual behaviour amongst 14- to 18-year olds is in general unsafe.

Assessment of physical activity. Physical activity is considered one of the most important determinants of health and components of a healthy lifestyle. Therefore, the question was raised whether the physical activity of the 14- to 18-year olds depends on the pupils learning outcomes. The analysis of the questionnaire results (e.g. analysis of one-factor ANOVA calculations) has shown $(p=0.260)$ that the physical activity of pupils is no different from the pupil learning outcomes. According to the survey, the percentage of physically active respondents ranged from $4.8 \%$ to $19.4 \%$ during the last 7 days. During this period, the largest proportion of pupils was physically active for 2 days $(19.4 \%$ of pupils who were surveyed) and 5 days (11.8\% of pupils who were surveyed) and $10.8 \%$ of respondents have indicated that they were completely physically inactive. The results also showed that boys are 1.9 times more physically active than girls $-65.6 \%$ of boys and only $34.4 \%$ of girls were physically active in the last 7 days.

The survey also intended to find out whether the girls and boys played computer games at the same level in the last 7 days. The analysis of the results showed that involvement of boys whilst playing computer games in the last 7 days is statistically significantly different from the involvement of girls $(\mathrm{p}=0.000)$. Girls played computer games 3.2 times less than the boys $-20.7 \%$ and $67.2 \%$, respectively. Even $93.9 \%$ of boys have indicated that they played video games for $5 \mathrm{~h}$ or more per day.

The general peculiarities of the implementation of preventive activities in Lithuania: comparison with the results of the questionnaire survey. As it was mentioned in section on 'Methodology', in the second stage of the research, the data obtained during the questionnaire survey was compared with the general results describing the preventive actions in the Republic of Lithuania, which was received during the state-organised Survey of the Lithuanian general education schools on the implementation of prevention programmes in general education schools in the 2015-2016 academic year (see Auškelis et al. 2016). The general results of this state-level study showed that prevention activities in Lithuanian general education schools are focused on the deployment of various preventive programmes. For example, the already-mentioned results showed that at least one prevention programme was implemented in $62.8 \%$ schools of Lithuania and $37.2 \%$ of schools in Lithuania hasn't implemented any preventive programmes at all. The study also tried to find out whether participation of schools in the implementation of prevention programmes was related to the type of school. The 
results showed that at least one prevention programme was implemented in most junior gymnasiums $(87.6 \%)$, in two-thirds of primary and secondary schools and only in $51.6 \%$ gymnasiums attended by 14- to 18 -year olds.

The results also showed that in one gymnasium (the highest level/type of general education school), only one preventive programme was usually implemented (46.4\% of all cases); quite often, two programmes were implemented $(32.5 \%$ of all cases); and less often, three programmes were implemented (15.2\% of all cases). Usually, gymnasiums are implementing violence and bullying prevention programmes $(38.8 \%$ of all cases) and psychoactive substance abuse prevention programmes (12.4\% of all cases).

Analysis of this data shows that only $18.6 \%$ of teachers in the gymnasiums have worked based on violence and bullying prevention programmes. According to the other data provided by schools, only $4.5 \%$ of violence and bullying prevention programmes in gymnasiums were attended by all pupils and in the rest of schools, this number has reached only $22.5 \%$ of all pupils. Only $20.6 \%$ of pupils of gymnasiums in total have ever participated in violence and bullying prevention programmes. These figures can be explained on the basis that so far there is no selective general violence and bullying prevention programme for pupils in ninth to twelfth grades at the national level at all.

Only $12.4 \%$ of all gymnasiums in Lithuania have implemented psychoactive substance abuse prevention programmes. The state study (Auškelis et al. 2016) has found that these programmes were attended by a very small number of pupils (10.2\%) and teachers (2.4\%). Although the use of psychoactive substances in schools remains a problem in the country, only $12.4 \%$ of gymnasiums have implemented specific substance abuse prevention programmes. They involved only a small part of the country's general education schools and even smaller proportion of students and teachers.

Effects of the preventive activities towards adolescent risky behaviours: comparison of the results (Fig. 2):

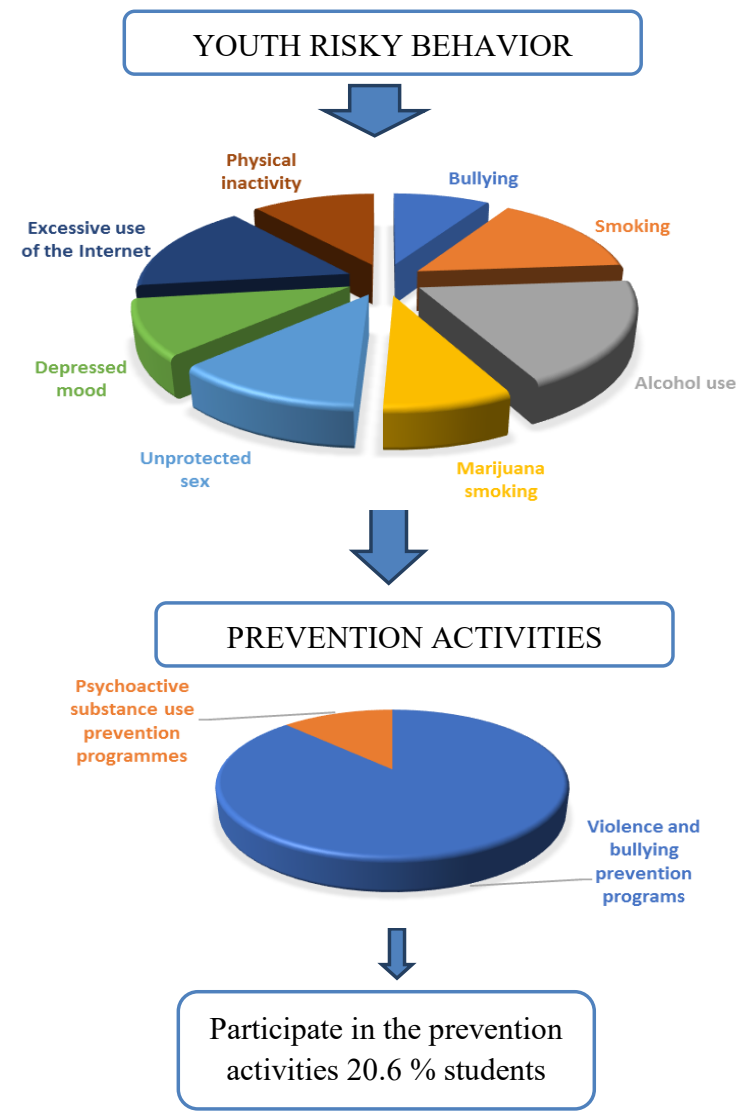

Fig. 2. Youth risky behaviour and factually implemented preventive activities in Lithuania 
The analysis of the risky behaviours of 14- to 18-year olds, which was conducted by the author and based on the questionnaire survey in Vilnius city, and the comparison of this analysis with the abovementioned data describing ongoing overall prevention activities in Lithuania (in 2015-2016) show the obvious gap between the problems experienced by young people and preventive activities that are selected for the factual implementation. Currently, Lithuania is increasingly focused on the prevention of violence against children as well as the problems of finding effective ways to reduce bullying in the general education schools. However, the implementation of preventive actions and the methods that are selected for the implementation of preventive measures does not correspond the actual problems experienced by youth (abuse of psychoactive substances, sedentary lifestyle, etc.) (Fig. 2).

\section{Conclusions}

The results of the survey questionnaire based on the surveying of pupils in the Lithuanian schools of general education during December 2016 (in the city of Vilnius, the capital of the Republic of Lithuania) about the risky behaviour (unsafe behaviour in certain situations, psychoactive substance abuse, physical inactivity, etc.) between 14 and 18 years old adolescents has showed that the most important factors that determine the adolescent risky behaviour are their gender and age. The survey shows that, in general, risky behaviour (such as unsafe driving using various transport mean, travelling with a drunk person and involvement in a physical fighting) is more typical to boys than to girls. However, there are some areas in which the population of girls has also shown worse attitudes than boys towards certain forms of risky behaviour or social risk factors; this can be attributed to the bullying in a cyberspace, prevalence of the depressed mood, consumption of alcohol and physical inactivity. The riskiest period for both boys and girls is 16 years of age, as during this age, pupils suffer from the highest levels of bullying, quite widespread prevalence of a depressive state of mind. Besides, as the results of the survey showed, 16-year olds usually start to use psychoactive substances (to smoke cannabis) and are getting started to be involved in sexual relationships.

On the other hand, the general situation in Lithuania related to the organisation of preventive activities in the past years (2015-2016) can be characterised by such general tendencies that: (i) despite the quite large overall number of general education schools that implemented at least one preventive programme (more than $60 \%$ of all general education schools have participated in these activities), in reality, only a small number of pupils and teachers have participated (participation percentage haven't exceeded $30 \%$ of all pupils and teachers). Most prevention programmes have been implemented in the lower grades and in the lower levels of general education schools, such as junior gymnasiums and primary and secondary schools. Only about a half $(51 \%)$ of general education schools of the highest level (i.e. gymnasiums) have participated in the preventive activities, even though largest part of adolescents belonging to the highest risk group (according to the age factor, i.e. 16-year olds) are learning in the gymnasiums. The most common types of implemented preventive programmes were violence and bullying prevention programmes.

The comparison of the results of the questionnaire survey and the official data about the implementation of preventive activities shows that, currently, the practical level planning and implementation of preventive activities in Lithuania is not related to the objectively existing types of risky behaviour between pupils. It is especially important to note that most of the programmes were not concentrated towards the riskiest age groups (such as 16-year olds) and towards types of general education schools where pupils belonging to the riskiest age groups are studying (i.e. gymnasiums). Instead of that, they focused on the prevention between pupils of lesser age cohorts. The topics of the preventive programmes don't cover some very problematic areas of risky behaviour, such as psychoactive substance abuse and inactive/sedentary lifestyle. As many aspects of the risky behaviour depend on the gender factor and are different between girls and boys, we should note the lack of gender-oriented prevention programmes. For this reason, it must be concluded that the implementation of the policy of risky behaviour prevention in Lithuanian general education schools amongst the pupils of higher grades (starting from the ninth grade) need to be reformed and reviewed by considering the established trends.

The results of the research prove the necessity to ensure that the youth risk behaviour surveys are 
carried out in a systematic and consistent manner, and prevention activities are planned regarding the problems that are encountered on the practical level (to avoid any gap between practical problems and performed preventive activities, which in Lithuania is observed at present time). The results of the study can also be used by the scholars and policy makers to explain the causes of teenager's risky behaviour, especially psychoactive substance use.

\section{References}

American Psychological Association Zero Tolerance Task Force. (2008). Are zero tolerance policies effective in the schools? An evidentiary review and recommendations. American Psychologist, (63), 852-862.

Astor, R. A., Benbenishty, R., Estrada J. (2009). School violence and theoretically atypical schools: The principal's centrality in orchestrating safe schools. American Educational Research Journal, (46), 423-461.

Auškelis, R., Dulinskaitè, I., Valantiejienè, S. (2010). Lietuvoje igyvendinamos prevencinès programos. Tarptautineje praktikoje taikomos prevencinès programos ataskaita [Preventive programs implemented in Lithuania. The report on the preventive programs which are applied in international practice]. Vilnius: Specialiosios pedagogikos ir psichologijos centras. Available from Internet: http://www.sppc.lt/index. php? 1767916592.

Auškelis, R., Bieliūnè, S., Ignatavičienė, K., Stupurienė, V., Šiautkulis, R., Valantiejienė, S. (2016). Prevencinių programu igyvendinimas Lietuvos bendrojo ugdymo mokyklose 2015-2016 mokslo metais [Implementation of the preventive programs in the Lithuanian schools of general education in 2015-2016 academic years]. Vilnius: Specialiosios pedagogikos ir psichologijos centras. Available from Internet: https://www.smm.lt/uploads/ documents/kiti/PREVENCINI\%C5\%B2\%20PROGRAM\%C5\%B2.pdf.

Bankauskienè, I. (2013). Psichoaktyviuju medžiagu vartojimo prevencija: samprata ir modeliai [Psychoactive substance abuse prevention: the concept and models] Vilnius: Narkotikų, tabako ir alkoholio kontroles departamentas.

Botvin, G. J., Griffin, K. W. (2007). School-based Programmes to Prevent Alcohol, Tobacco and Other Drug Use. International Review of Psychiatry, 19 (6), 607-615.

Christofides, E., Muise, A., Desmarais, S. (2012). Risky dislocures on facebook: the effect of having a bad experience on online behavior. Journal of Adolescent Research, 27 (6), 714-728.

Compas, B. E. (2004). Processes of risk and resilience during adolescence. In: Lerner R. M., Steinberg, L. (eds.), Handbook of Adolescent Psychology. New Jersey: John Wiley \& Sons Inc., 263-296.

Costa, F. M. (2008). Problem-Behavior Theory - A Brief Overview. Available from Internet: http://www.colorado.edu/ibs/jessor/pb_theory.html.

Costello, D. M., Swendsen, J., Rose J. S., Dierker, L. C. (2008). Risk and protective factors associated with trajectories of depressed mood from adolescence to early adulthood. Journal of Consulting and Clinical Psychology, 76 (2), 173-183.

Dowdell, E., Burgess, A., Cavanaught, D. (2009). Clustering of Internet risk behaviors in a middle school student population. School Health, 79 (11), 547-553.

Duberstein, L., Boggess, S., Williams, S. (2000). Teen risk-taking: A Statistical Portrait. Urban Institute. Available from Internet: http://www.urban.org.

Eaton, D. K., Kann, L., Kinchen, S., Shanklin, S., Flint, K. H., Hawkins, J., Harris, W. A., Lowry, R., McManus, T., Chyen, D., Whittle, L., Lim, C., Wechsler, H. (2011). Youth Risk Behavior Surveillance - United States. The Morbidity and Mortality Weekly Report, 61 (4), 1-162.

Erikson, E. H. (2004). Vaikyste ir visuomene [Childhood and society]. Vilnius: Adomo Jakšto spaustuvè.

Farmer T. W., et al. (2013). Conceptual Foundations and Components of a Contextual Intervention to Promote Student Engagement During Early Adolescence: The Supporting Early Adolescent Learning and Social Success (SEALS) Model. Journal of Educational and Psychological Consultation, 23 (2), 115-139.

Feldstein, S. W., Miller, W. R. (2006). Substance use and risk-taking among adolescents. Journal of Mental Health, 15 (6), 633-643.

Gaigalaite, G. (2007). Valgymo sutrikimu rizikos paplitimas tarp moteru [The occurrence of eating disorders risk among women and its determinants]. Kaunas: Lietuvos kūno kultūros akademija. 
Green, K., Krcmar, M., Walters, R. H., Rubin, D. L., Hale, J., Hale, L. (2000). Targeting adolescent risk-taking behaviors: the contribution of egocentrism and sensation-seeking. Journal of Adolescence, 23 (5), 439-461.

Guan, S., Subrahmanyam, K. (2009). Youth Internet use: risks and opportunities. Current Opinion in Psychiatry, (22), 351-356.

Guzman, M. R., Bosch, K. R. (2007). High-risk behaviors among youth. NebGuide. Families, Adolescence \& Youth. Available from Internet: http://www.ianrpubs.unl.edu/pages/publi $\neg$ cationD.jsp?publicationId=786.

Lithuanian Education Management Information System (ITC Education Management Information System) (2017). [Accessed 17.04.2017]. Available from Internet: http://www.svis.smm.lt/.

Irish, L. A.(2011). Development, reliability and validity of the health risk behaviors inventory: a self-report measure of 7 current health risk behaviors. Open access thesis and dissertations. [Accessed 11.02.2017]. Available from: <http://rave.ohiolink.edu etdc/view?acc_num=kent1302034344>.

Jessor, R. (1998). New Perspectives on Adolescent Risk Behavior. Cambridge: Cambridge University Press.

The United Nations Convention on the Rights of the Child (1995). Official Gazette, 60, (1501).

Keeler, H. J., Kaiser, M. M. (2010). An Integrative Model of Adolescent Health Risk Behavior. Journal of Pediatric Nursing, (25), 126-137.

Kolpakova, O., Liubimova, A., Levina, O. (2012). Understanding risky online behavior of 14-17 years old Russian children. Available from Internet: http://www.childcentre.info/robert/public/Kolpakova.pdf.

Lenhart, A. (2009). Teens and Social Media. Available from Internet: http://isites.harvard.edu/fs/docs/icb.topic 786630.files/Teens\%20Social\%20Media\%20and\% 20Health\%20-\%20NYPH\%20Dept\%20Pew\%20Internet.pdf.

Law on Education of the Republic of Lithuania (2011). Official Gazette, 38, (1804).

Livingstone, S., Helsper, E. (2008). Parental mediation and children's internet use. Journal of Broadcasting \& Electronic Media, 52 (2), 581-599.

Lopes, P. N., Salovey, P. (2004). Toward a broader education. In: Walberg H. J., Wang M. C., Zins R. J. E., Weissberg, P. (eds.), Building school success on social and emotional learning. New York: Teachers College Press.

Milam, A.J., Furr-Holden, C.D.M., Leaf, P.J. (2010). Perceived School and Neighborhood Safety, Neighborhood Violence and Academic Achievement in Urban School Children. The Urban Review, 42 (5), 458-467.

Norkus, A. (2012). Sveika gyvensena Lietuvos studentu populiacijoje: edukacinis diagnostinis aspektas [Healthy lifestyle in the Lithuanian student population: the educational and diagnostic aspect]. Śauliai: Šiaulių universitetas.

Olsson, A., Fahlén, I., Janson, S. (2008). Health behaviours, risk-taking and conceptual changes among schoolchildren aged 7 to 19 years in semi-rural Sweden. Child: Care, Health and Development, 34 (3), 302-309.

Pickett, W., Schmid, H., Boyce, W. F., Simpson, K., Scheidt, P. C., Mazur, J., Molcho, M., King, M. A., Godeau, E., Overpeck, M., Aszmann, A., Szabo, M., Harel, Y. (2002). Multiple risk behavior and injury: an international analysis of young people. Archives of Pediatric \& Adolescent Medicine, 56 (8), 786-793.

Reeves, M. A., Kanan, L. M., Plog, E. M. (2010). Comprehensive Planning for Safe Learning Environments. New York: Taylor and Francis Group.

Ruangkanchanasetr, S., Plitponkarnpim, A., Hetrakul, P., Kongsakon, R. (2005). Youth risk behavior survey. Bangkok, Thailand: Department of Pediatrics, Faculty of Medicine, Ramathibodi Hospital, Mahidol University.

Sakalauskaitè, E., Tutkuvienè, J. (2009). Kūno įvaizdis: veiksniai ir sąsajos su fizine būkle [Body Image: Factors and Parallels with the Physical Status]. Laboratorine medicina, 4 (44), 15-19.

Schmidt, H., Voigt, K., Wikler, D. (2010). Carrots, sticks, and health care reform - problems with wellness incentives. The New England Journal of Medicine, 362 (20).

Sychareun, V., Thomsen, S., Faxelid, E. (2011). Concurrent multiple health risk behaviors among adolescents in Luangnamtha province, Lao PDR. BMC Public Health, 11 (36).

Sklad, M., et al. (2012). Effectiveness of school-based universal social, emotional, and behavioral programs: do they enhance students' development in the area of skill, behavior, and adjustment? Psychology in the Schools, 49 (9), 892-909. 